Scientific Journal Warsaw University of Life Sciences - SGGW

Problems of World Agriculture volume 17 (XXXII), number 4, 2017: 161-171

DOI: 10.22630/PRS.2017.17.4.92

Grzegorz Koszela $^{1}$, Luiza Ochnio ${ }^{2}$

Warsaw University of Life Sciences WULS - SGGW

\title{
Changes in Consumer Food Preferences in EU Countries from 2001-2013
}

\begin{abstract}
This paper attempts to rank EU countries according to changes in consumer food preferences between 2001 and 2013. The size of these changes was determined using a synthetic rate created for this purpose. This rate was intended to accommodate changes in consumption levels in 9 product groups per capita. It turns out that we may use the greatest possible measure of the structure's dissimilarity as an analogy to the Gini coefficient, to express this rate. Using the "ar" measure to compare structures of food consumption in two separate three-year time periods for each country, scientists may rank and group the countries according to the value of changes in consumer food preferences.
\end{abstract}

Key words: dissimilarity of structures, synthetic rate, ranking, multidimensional data analysis, grade data analysis, consumer food preferences, EU

JEL Classification: C01, C18, Q10

\section{Introduction}

Consumer food preferences are an important indicator for agricultural production, especially when it comes to finding new markets. Obviously, these preferences are modified in the long run. However, due to geographical, climatic, cultural and other conditions these changes will not proceed diametrically. But, undoubtedly, consumption of various food products is changing in each country as borders open up, as in the case of countries that joined the European Union, or due to increased nutritional awareness of consumers (Małysa-Kaleta, 2003). For example, in Poland after 1990, there was an increase in the diversity of food consumption (Grzelak, Gałąka, 2013) whereas research in the Mediterranean countries indicates a gradual resignation from traditional food in this region (Balanza et al., 2007). This paper attempts to analyze the total changes in consumer food preferences in EU countries between 2001 and 2013. To avoid listing individual product groups, one approach applied to this issue may be to compare structural profiles in two extreme time periods for each country and to build a synthetic rate that will definitely determine the value of these changes. Thus, the aim of the study is to rank the EU countries according to the value of changes in consumption of different group of food products in EU countries between 2001 and 2013 and to divide countries into groups according to similar level of changes in food consumption over the years.

${ }^{1} \mathrm{PhD}$, Department of Econometrics and Statistics, Faculty of Applied Informatics and Mathematics WULSSGGW, Nowoursynowska 159,02-776 Warsaw, e-mail: grzegorz_koszela@sggw.pl; https://orcid.org/0000-0003-4175-4450

${ }^{2} \mathrm{PhD}$, Department of Econometrics and Statistics, Faculty of Applied Informatics and Mathematics WULSSGGW, Nowoursynowska 159,02-776 Warsaw, e-mail: luiza_ochnio@sggw.pl; https://orcid.org/0000-0001-8875-7945 
The study used data in $\mathrm{kg}$ per capita on the consumed products in each country. The data came from the United Nations Food and Agriculture Organization (FAO) (www.fao.org). There is also information on the annual consumption of food products in the European Union between 2001 and 2013, divided into 14 product groups. To clarify obtained results some of the groups were excluded and some were combined. However, this did not affect the reliability of the study. Thus, 9 different variables were identified: $x_{1}$ Cereals - without beer, $\mathrm{x}_{2}$ - Sugar and sweeteners, $\mathrm{x}_{3}$ - Legumes and vegetables, $\mathrm{x}_{4}$ - Fruits without wine, $\mathrm{x}_{5}-$ Meat and offal, $\mathrm{x}_{6}-$ Milk without butter, $\mathrm{x}_{7}-$ Eggs, $\mathrm{x}_{8}-$ Fish and seafood, $\mathrm{x}_{9}$ - Potatoes and potato products.

The methods and tools used in this study are techniques of Multidimensional Data Analysis and Grade Data Analysis. The averages of variables from three consecutive years of two separate periods (years 2001-2003 and 2011-2013) were used in the comparative study. Then, one of the synthetic rates was used, which considered consumption levels in the product groups counted per capita. Calculation of this rate was based on the "ar" measure used for measuring the differentiation of two structures (Gastwirth, 1971; Arnold, 1987; Binderman et al., 2014).

\section{Certain problems related to measuring the dissimilarity of two structures}

First of all, since the structures of particular product groups will be compared in two separate three-year periods, we need to specify some problems related to the measurement of the structures' dissimilarity.

Regarding the measure of structure similarity, many proposals may be found in the literature, one of which seems to be especially popular - "Minkowski Metric" (Zimmermann, 1968; Jain, Dubes, 1988; Binderman et al., 2013; De Amorim, Mirkin, 2012). For example, if we have two structures: $\mathbf{X}$ and $\mathbf{Y}$,

where: $x_{i} \geq 0, \sum_{i=1}^{n} x_{i}=1, y_{i} \geq 0, \sum_{i=1}^{n} y_{i}=1$

Minkowski Metric of order $\mathrm{p}$ between two points has the following formula:

$$
\mathrm{d}(\mathbf{X}, \mathbf{Y})=\left(\sum_{\mathrm{i}=1}^{\mathrm{n}}\left|\mathrm{x}_{\mathrm{i}}-\mathrm{y}_{\mathrm{i}}\right|^{\mathrm{p}}\right)^{\frac{1}{\mathrm{p}}}
$$

It meets 2 conditions:

1. The distance $d$ between objects of the same structure is equal to 0 , so: $d(x, x)=0$;

2. The distance between object $Y$ and object $X$ is the same as between $X$ and $Y$ and is not less than 0, so: $d(x, y)=d(y, x) \geq 0$.

Sometimes there may be doubt about the fulfillment of the third condition by the structures' dissimilarity rate (it is easy to explain by referring to the concentration measurement) (Zimmermann,1968): 
3. The distance measure changes according to the assumed "transfer sensitivity" in the concentration rates, where the increase of the dissimilarity coefficient with the constant transfer rate $(\epsilon)$ is the greater, the "richer" the transfer object is:

$$
\underset{\mathrm{n} \geq \mathrm{k}>\mathrm{j}>\mathrm{i} \geq 1}{\wedge} \mathrm{d}\left(\mathrm{x}, \mathrm{x}_{\mathrm{ij}, \varepsilon}\right) \leq \mathrm{d}\left(\mathrm{x}, \mathrm{x}_{\mathrm{ik}, \varepsilon}\right)
$$

$$
\text { where: } \begin{aligned}
& x=\left(x_{1}, \ldots, x_{i}, \ldots, x_{j}, \ldots, x_{k}, \ldots, x_{n}\right) \\
& x_{i j, \varepsilon}=\left(x_{1}, \ldots, x_{i}-\varepsilon, \ldots, x_{j}+\varepsilon, \ldots, x_{k}, \ldots x_{n}\right) \\
& x_{i k, \varepsilon}=\left(x_{1}, \ldots, x_{i}-\varepsilon, \ldots, x_{j}, \ldots, x_{k}+\varepsilon, \ldots x_{n}\right)
\end{aligned}
$$

In this study, this postulate will be relevant, but it will not be exactly used in this sense (but studies in which the transfer of consumption in relation to time for particular groups of products is important and are also possible).

Building the dissimilarity rate of structures that fail to meet the third condition may be based on the concentration rate, e.g.: $\mathrm{G}$ - Gini coefficient (3), which is doubled in area $\left(\mathrm{P}_{\mathrm{A}}\right)$ between the diagonal of the square representing the egalitarian distribution, and the Lorentz curve - f(t) (Fig. 1) (Gini, 1914; Glasser ,1962; Gastwirth, 1971; Arnold,1987):

$$
G=2 \cdot P_{A}=1-2 \cdot \int_{0}^{1} f(t) d t
$$

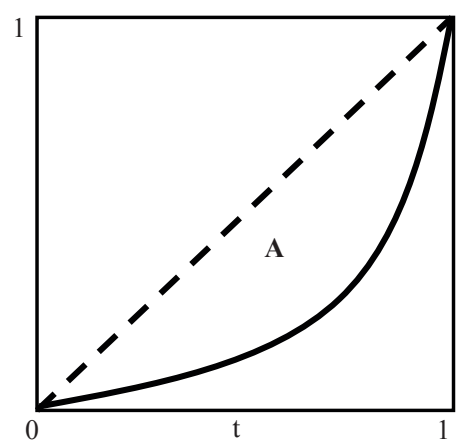

Fig. 1. Lorenz curve - explanatory figure

Source: Authors' own elaboration.

By analogy with the Lorenz curve, the dissimilarity of the Y-structure to the X-structure may be presented as a broken line joining some points. These points have coordinates being, in this case, the subsequent cumulative structures (Binderman et al., 2014; Koszela, 2016):

$$
(0 ; 0),\left(\mathrm{x}_{1}, \mathrm{y}_{1}\right),\left(\mathrm{x}_{1}+\mathrm{x}_{2} ; \mathrm{y}_{1}+\mathrm{y}_{2}\right), \ldots,\left(\mathrm{x}_{1}+\ldots+\mathrm{x}_{\mathrm{n}} ; \mathrm{y}_{1}+\ldots+\mathrm{y}_{\mathrm{n}}\right)
$$

For example, we may compare structures of product groups (w) that are part of the annual consumer consumption in Denmark and in Poland in years 2011-2013 (Table 1). 
If we join vertices of corresponding cumulative structures of components included in annual consumer consumption of concerned countries, we obtain the desired L1 (Fig. 2) and we are able to determine the structural dissimilarity for Poland and Denmark.

Table 1. Average annual consumption of product groups in $\mathrm{kg} /$ person and their structures for Denmark (DK) and Poland (PL) in years 2011-2013

\begin{tabular}{|c|c|c|c|c|c|c|}
\hline \multirow[b]{2}{*}{ 2011-2013 } & \multicolumn{3}{|c|}{ Denmark (DK) } & \multicolumn{3}{|c|}{ Poland (PL) } \\
\hline & $\mathrm{kg} /$ pers & $\%\left(\mathrm{w}_{\mathrm{DK}}\right)$ & $\mathrm{w}_{\mathrm{DK}}$ cum. & $\mathrm{kg} /$ pers & $\%\left(\mathrm{w}_{\mathrm{PL}}\right)$ & $\mathrm{w}_{\mathrm{PL}}$ cum. \\
\hline $\mathrm{x} 1$ & 134.03 & $15.44 \%$ & $15.44 \%$ & 151.36 & $19.35 \%$ & $19.35 \%$ \\
\hline$x 2$ & 54.73 & $6.30 \%$ & $21.74 \%$ & 44.19 & $5.65 \%$ & $25.00 \%$ \\
\hline $\mathrm{x} 3$ & 113.21 & $13.04 \%$ & $34.78 \%$ & 120.96 & $15.46 \%$ & $40.46 \%$ \\
\hline $\mathrm{x} 4$ & 115.18 & $13.27 \%$ & $48.05 \%$ & 57.22 & $7.32 \%$ & $47.78 \%$ \\
\hline $\mathrm{x} 5$ & 83.93 & $9.67 \%$ & $57.72 \%$ & 78.81 & $10.08 \%$ & $57.86 \%$ \\
\hline$x 6$ & 267.83 & $30.85 \%$ & $88.57 \%$ & 201.30 & $25.73 \%$ & $83.59 \%$ \\
\hline$\times 7$ & 15.26 & $1.76 \%$ & $90.32 \%$ & 8.14 & $1.04 \%$ & $84.63 \%$ \\
\hline $\mathrm{x} 8$ & 23.00 & $2.65 \%$ & $92.97 \%$ & 10.20 & $1.30 \%$ & $85.93 \%$ \\
\hline $\mathrm{x} 9$ & 61.00 & $7.03 \%$ & $100.00 \%$ & 110.02 & $14.07 \%$ & $100.00 \%$ \\
\hline Total & 868.17 & $100.00 \%$ & & 782.19 & $100.00 \%$ & \\
\hline
\end{tabular}

Source: Authors' own elaboration.

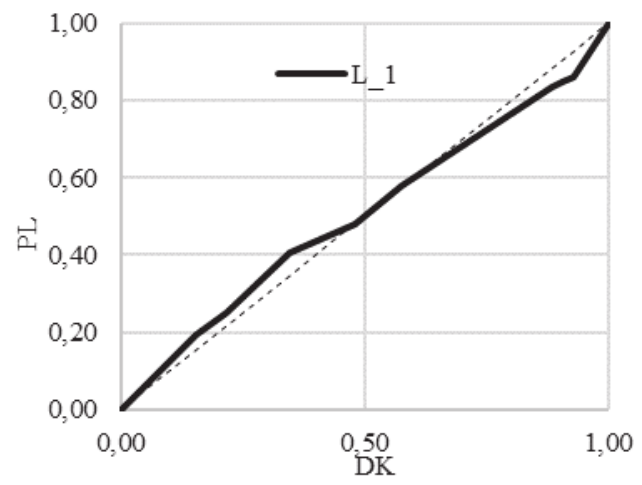

Fig.2. Curve of cumulative structures for Denmark and Poland (2011-2013)

Source: Authors' own elaboration.

The dissimilarity measure of the structure $\mathbf{Y}$ to the structure $\mathbf{X}$, also by analogy, but this time with the Gini coefficient, is the "ar" measure (5) (Gastwirth, 1971; Arnold, 1987; Binderman, 2014). In his case $\mathrm{C}(\mathrm{t})$ is an analogy for $\mathrm{f}(\mathrm{t})$ in formula (3).

$$
\begin{gathered}
\operatorname{ar}(\mathbf{Y}: \mathbf{X})=\operatorname{ar}\left(\mathrm{C}_{[\mathbf{Y : X}]}\right)=1-2 \int_{0}^{1} \mathrm{C}_{[\mathbf{Y}: \mathbf{X}]}(\mathrm{t}) \mathrm{dt} \\
\text { for L1 }: \operatorname{ar}(\mathbf{P L}: \mathbf{D K})=\operatorname{ar}\left(C_{[\mathbf{P L}: \mathbf{D K}]}\right)=-0.004
\end{gathered}
$$

However, the value of the ar measure depends mainly on the arrangement of the individual features. Different features arrangement (Table 2) results in different curve (Fig 3 - compare L1 and L2) and different value of ar measure. 
Table 2. Cumulative structures for Denmark and Poland for 2 different component arrangements (2011-2013)

\begin{tabular}{|c|c|c|c|c|c|}
\hline \multicolumn{3}{|c|}{ L1 } & \multicolumn{3}{|c|}{ L2 } \\
\hline$X$ & $\mathrm{~W}_{\mathrm{DK} \text { cum }}$ & $\mathrm{W}_{\text {PL cum }}$ & $\mathrm{X}$ & $\mathrm{W}_{\mathrm{DK} \text { cum }}$ & $\mathrm{w}_{\text {PL cum }}$ \\
\hline $\mathrm{x}_{1}$ & 0.15 & 0.19 & $\mathrm{X}_{4}$ & 0.13 & 0.07 \\
\hline $\mathrm{x}_{2}$ & 0.22 & 0.25 & $\mathrm{x}_{6}$ & 0.44 & 0.33 \\
\hline $\mathrm{x}_{3}$ & 0.35 & 0.40 & $\mathrm{X}_{8}$ & 0.47 & 0.34 \\
\hline $\mathrm{x}_{4}$ & 0.48 & 0.48 & $\mathrm{X}_{5}$ & 0.56 & 0.44 \\
\hline $\mathrm{X}_{5}$ & 0.58 & 0.58 & $\mathrm{x}_{2}$ & 0.63 & 0.50 \\
\hline $\mathrm{x}_{6}$ & 0.89 & 0.84 & $x_{7}$ & 0.64 & 0.51 \\
\hline $\mathrm{x}_{7}$ & 0.90 & 0.85 & $\mathrm{X}_{9}$ & 0.72 & 0.65 \\
\hline $\mathrm{x}_{8}$ & 0.93 & 0.86 & $\mathrm{x}_{1}$ & 0.87 & 0.85 \\
\hline $\mathrm{X}_{9}$ & 1.00 & 1.00 & $\mathrm{x}_{3}$ & 1.00 & 1.00 \\
\hline
\end{tabular}

Source: Authors' own elaboration.

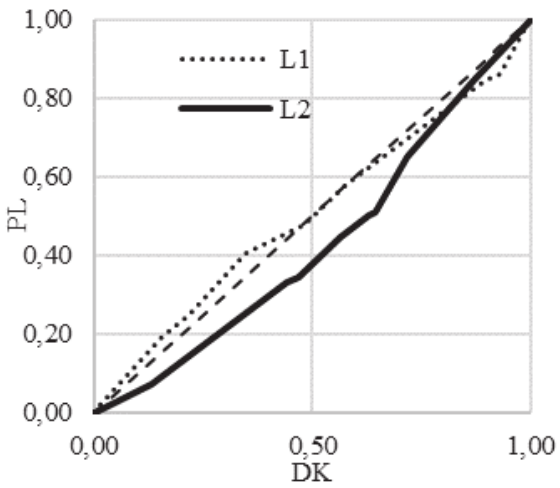

Fig.3. Curves of cumulative structures for Denmark and Poland for 2 different component arrangements (20112013)

Source: Authors' own elaboration.

$$
\text { for L2 : } \operatorname{ar}(\mathbf{P L}: \mathbf{D K})=\operatorname{ar}\left(C_{[\mathbf{P L}: \mathbf{D K}]}\right)=0.141
$$

Since the value of ar dissimilarity measure depends on a curve (broken line), i.e. feature arrangement, it is worth considering how to get the greatest value of the dissimilarity of two structures. It turns out that when we put the components in a nondecreasing order in relation to the quotient of corresponding structures (Table 3), we will find the largest possible area of the figure bounded by the curve (Fig. $4-\mathrm{L}_{\max }$ ) and the diagonal of the square. It will give the greatest possible ar dissimilarity rate (in this case between Polish and Danish food consumers). This rate may be marked with $\operatorname{ar}_{\max }(7)$ and since it always has a positive value, treat it as both a measure of dissimilarity and distance (Borkowski, Szczesny, 2005; Ząbkowski, Szczesny, 2012).

$$
\operatorname{ar}_{\max }(\mathbf{Y}: \mathbf{X})=\operatorname{ar}_{\max }\left(\mathrm{C}_{\max [\mathbf{Y}: \mathbf{X}]}\right)=1-2 \int_{0}^{1} \mathrm{C}_{\max [\mathbf{Y}: \mathbf{X}]}(\mathrm{t}) \mathrm{dt}
$$


Table 3. Cumulative structures for Denmark and Poland to order components non-decreasingly in relation to the quotient of corresponding structures (2011-2013)

\begin{tabular}{c|rrrrrr}
\hline \multicolumn{7}{c}{ L max } \\
\hline
\end{tabular}

Source: Authors' own elaboration.

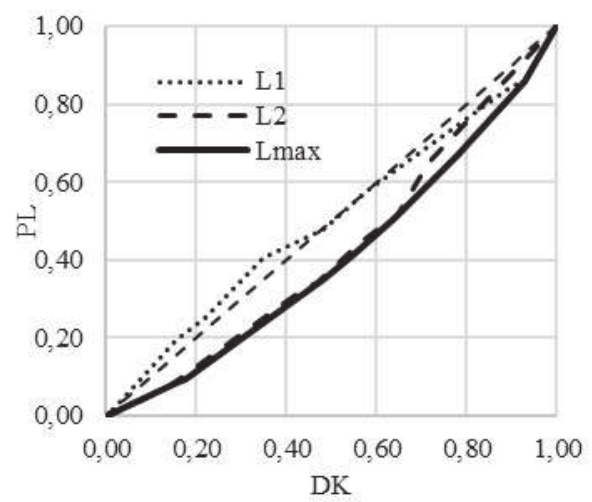

Fig. 4 Curves of cumulative structures for Denmark and Poland for 3 different component arrangements and (2011-2013)

Source: Authors' own elaboration.

The $\mathrm{ar}_{\max }$ value, which is the measure of the greatest dissimilarity between Poland and Denmark in the period 2011-2013, to order the components non-decreasingly in relation to the quotient of corresponding structures, in this case is:

$$
\text { for } \mathrm{L}_{\max }: a r_{\max }(\mathbf{P L}: \mathbf{D K})=0.187
$$

However, it raises a question: why may the $\operatorname{ar}_{\max }$ measure sometimes be more useful to measure the structural dissimilarity (distances) of compared objects - in this case the structures of product group consumption in EU countries? We will use an example to explain this issue. We need to measure the dissimilarity of two theoretical objects P1 and $\mathrm{P} 2$ to another theoretical object $\mathrm{P} 0$. Table 4 shows sample structures in each product group for the compared objects. 
Table 4. Theoretical data for sample objects P1 and P2 compared to another sample object P0

\begin{tabular}{|c|c|c|c|}
\hline$X$ & $\begin{array}{c}\mathrm{P} 0 \\
\%\left(\mathrm{w}_{\mathrm{P} 0}\right)\end{array}$ & $\begin{array}{c}\mathrm{P} 1 \\
\%\left(\mathrm{w}_{\mathrm{P} 1}\right)\end{array}$ & $\begin{array}{c}\mathrm{P} 2 \\
\%\left(\mathrm{w}_{\mathrm{P} 2}\right)\end{array}$ \\
\hline $\mathrm{x}_{1}$ & $13.00 \%$ & $17.00 \%$ & $15.00 \%$ \\
\hline $\mathrm{x}_{2}$ & $7.00 \%$ & $3.00 \%$ & $5.00 \%$ \\
\hline $\mathrm{x}_{3}$ & $10.00 \%$ & $10.00 \%$ & $8.00 \%$ \\
\hline $\mathrm{X}_{4}$ & $10.00 \%$ & $10.00 \%$ & $12.00 \%$ \\
\hline $\mathrm{x}_{5}$ & $10.00 \%$ & $10.00 \%$ & $12.00 \%$ \\
\hline $\mathrm{X}_{6}$ & $30.00 \%$ & $30.00 \%$ & $28.00 \%$ \\
\hline $\mathrm{x}_{7}$ & $5.00 \%$ & $5.00 \%$ & $3.00 \%$ \\
\hline $\mathrm{x}_{8}$ & $5.00 \%$ & $5.00 \%$ & $7.00 \%$ \\
\hline $\mathrm{X}_{9}$ & $10.00 \%$ & $10.00 \%$ & $10.00 \%$ \\
\hline Total & $100.00 \%$ & $100.00 \%$ & $100.00 \%$ \\
\hline
\end{tabular}

Source: Authors' own elaboration.

It turns out that the structural dissimilarity rate of objects P1 and P2 to the object P0, defined, e.g. as Minkowski Metric in the Euclidean space (8), is identical despite the intuitively clear differences between the compared objects.

$$
\begin{aligned}
& \mathrm{d}(\mathbf{X}, \mathbf{Y})=\left(\sum_{\mathrm{i}=1}^{\mathrm{n}}\left|\mathrm{x}_{\mathrm{i}}-\mathrm{y}_{\mathrm{i}}\right|^{2}\right)^{\frac{1}{2}} \\
& d(\mathbf{P 0}, \mathbf{P 1})=0.05657 \quad d(\mathbf{P 0}, \mathbf{P 2})=0.05657
\end{aligned}
$$

When we order the components non-decreasingly in relation to the quotient of corresponding structures (Table 5) and use the $\operatorname{ar}_{\max }$ measure (formula 7), the dissimilarity rates in both cases will be different.

Table 5. Theoretical data arranged non-decreasingly in relation to the quotient of corresponding structures for exemplary objects $\mathrm{P} 1$ and $\mathrm{P} 2$ compared to the exemplary object $\mathrm{P} 0$

\begin{tabular}{crrrrr}
\hline $\mathrm{X}$ & $\begin{array}{c}\mathrm{P} 0 \\
\%\left(\mathrm{w}_{\mathrm{P} 0}\right)\end{array}$ & $\begin{array}{c}\mathrm{P} 1 \\
\%\left(\mathrm{w}_{\mathrm{P} 1}\right)\end{array}$ & $\mathrm{X}$ & $\begin{array}{c}\mathrm{P} 0 \\
\%\left(\mathrm{w}_{\mathrm{P} 0}\right)\end{array}$ & $\begin{array}{c}\mathrm{P} 2 \\
\%\left(\mathrm{w}_{\mathrm{P} 1}\right)\end{array}$ \\
\hline $\mathrm{X}_{2}$ & $7.00 \%$ & $\mathbf{3 . 0 0 \%}$ & $\mathrm{X}_{7}$ & $5.00 \%$ & $\mathbf{3 . 0 0 \%}$ \\
$\mathrm{X}_{6}$ & $30.00 \%$ & $30.00 \%$ & $\mathrm{X}_{2}$ & $7.00 \%$ & $\mathbf{5 . 0 0 \%}$ \\
$\mathrm{X}_{8}$ & $5.00 \%$ & $5.00 \%$ & $\mathrm{X}_{3}$ & $10.00 \%$ & $\mathbf{8 . 0 0 \%}$ \\
$\mathrm{X}_{4}$ & $10.00 \%$ & $10.00 \%$ & $\mathrm{X}_{6}$ & $30.00 \%$ & $\mathbf{2 8 . 0 0 \%}$ \\
$\mathrm{X}_{5}$ & $10.00 \%$ & $10.00 \%$ & $\mathrm{X}_{9}$ & $10.00 \%$ & $10.00 \%$ \\
$\mathrm{X}_{3}$ & $10.00 \%$ & $10.00 \%$ & $\mathrm{x}_{1}$ & $13.00 \%$ & $\mathbf{1 5 . 0 0 \%}$ \\
$\mathrm{X}_{9}$ & $10.00 \%$ & $10.00 \%$ & $\mathrm{X}_{5}$ & $10.00 \%$ & $\mathbf{1 2 . 0 0 \%}$ \\
$\mathrm{X}_{7}$ & $5.00 \%$ & $5.00 \%$ & $\mathrm{X}_{4}$ & $10.00 \%$ & $\mathbf{1 2 . 0 0 \%}$ \\
$\mathrm{X}_{1}$ & $13.00 \%$ & $\mathbf{1 7 . 0 0 \%}$ & $\mathrm{X}_{8}$ & $5.00 \%$ & $\mathbf{7 . 0 0 \%}$ \\
Total & $100 \%$ & $100 \%$ & Total & $100 \%$ & $100 \%$ \\
\hline
\end{tabular}

Source: Authors' own elaboration. 
As expected, object P1 is more similar to P0 than P2 because of the lower ar ${ }_{\max }$ value:

$$
a r_{\max }(\mathbf{P 0}: \mathbf{P 1})=0.072 \quad a r_{\max }(\mathbf{P 0}: \mathbf{P 2})=0.108 \text {. }
$$

\section{Results}

To determine the significance of changes in consumer preferences, we may calculate the $\operatorname{ar}_{\max }$ rate analogously by comparing the food consumption structures for individual EU countries in the two separate periods - 2001-2003 and 2011-2013. For example, for Poland, determining the value of these changes means calculating the $\mathrm{ar}_{\max }$ value for relevant non-decreasing arrangement of the components in these two periods in relation to the quotient of corresponding structures (Table 6).

Table 6. Average annual consumption of product groups in $\mathrm{kg} /$ person, their structures and cumulative structures for Poland (PL) in years 2001-2003 (PL1) and 2011-2013

\begin{tabular}{|c|c|c|c|c|c|c|c|}
\hline \multirow[b]{2}{*}{$\mathrm{X}$} & \multicolumn{3}{|c|}{ PL1 (2001-2003) } & \multicolumn{3}{|c|}{ PL2 (2011-2013) } & \multirow{2}{*}{$\mathrm{W}_{\mathrm{PL} 2} / \mathrm{W}_{\mathrm{PL} 1}$} \\
\hline & $\mathrm{kg} /$ pers & $\%\left(\mathrm{~W}_{\mathrm{PL} 1}\right)$ & $\mathrm{W}_{\text {PL1 cum. }}$ & $\mathrm{kg} /$ pers & $\%\left(\mathrm{~W}_{\mathrm{PL} 2}\right)$ & $\mathrm{W}_{\text {PL2 cum. }}$ & \\
\hline $\mathrm{x}_{7}$ & 11.55 & $1.45 \%$ & $1.45 \%$ & 8.14 & $1.04 \%$ & $1.04 \%$ & 0.7181 \\
\hline $\mathrm{X}_{9}$ & 130.55 & $16.39 \%$ & $17.84 \%$ & 110.02 & $14.07 \%$ & $15.11 \%$ & 0.8583 \\
\hline $\mathrm{x}_{2}$ & 45.98 & $5.77 \%$ & $23.61 \%$ & 44.19 & $5.65 \%$ & $20.76 \%$ & 0.9790 \\
\hline $\mathrm{x}_{3}$ & 123.67 & $15.52 \%$ & $39.13 \%$ & 120.96 & $15.46 \%$ & $36.22 \%$ & 0.9962 \\
\hline $\mathrm{x}_{1}$ & 153.45 & $19.26 \%$ & $58.39 \%$ & 151.36 & $19.35 \%$ & $55.57 \%$ & 1.0047 \\
\hline $\mathrm{x}_{6}$ & 195.97 & $24.60 \%$ & $82.99 \%$ & 201.30 & $25.73 \%$ & $81.31 \%$ & 1.0462 \\
\hline $\mathrm{x}_{5}$ & 75.92 & $9.53 \%$ & $92.52 \%$ & 78.81 & $10.08 \%$ & $91.38 \%$ & 1.0573 \\
\hline $\mathrm{x}_{8}$ & 9.04 & $1.13 \%$ & $93.65 \%$ & 10.20 & $1.30 \%$ & $92.68 \%$ & 1.1489 \\
\hline $\mathrm{x}_{4}$ & 50.57 & $6.35 \%$ & $100.00 \%$ & 57.22 & $7.32 \%$ & $100.00 \%$ & 1.1526 \\
\hline Total & 796.70 & $100.00 \%$ & & 782.19 & $100 \%$ & & \\
\hline
\end{tabular}

Source: Authors' own elaboration.

In this case the $\operatorname{ar}_{\max }$ dissimilarity rate indicating the value of changes in Polish consumers preferences over the 10 -year period is:

$$
\operatorname{ar}_{\max }(\mathrm{PL} 1: \mathrm{PL2})=0.04032 \text {. }
$$

Table 7 shows the $a_{\max }$ dissimilarity rates for each EU country. They compare (as in the Polish example) the structure of food consumption in two extreme periods 2001-2003 and 2011-2013. Calculating the $\mathrm{ar}_{\max }$ rates allows us to create a ranking that values countries where the changes were most important. If we treat the $\mathrm{ar}_{\max }$ rates as synthetic rates $Q_{i}$ describing the values of changes in a food consumption structure in years 20012013, we may divide these countries into groups. The method of distribution may be, e.g. quite clear division used by Professor Kukuła (Kukuła, 2010, 2012, 2014a, 2014b; Ząbkowski, Szczesny, 2012). After the arrangement of synthetic variable $\mathrm{Q}_{\mathrm{i}}$ according to non-decreasing values (in this case $\left.Q_{i}=a r_{\max }\right)$, we may calculate the range $R\left(Q_{i}\right)$ for this variable:

$$
R\left(Q_{i}\right)=\max Q_{i}-\min Q_{i}=0.18299 .
$$

If we decide to divide the objects into 3 groups, we need to determine the size of the division parameter $\mathrm{k}$ according to formula: 


$$
k=\frac{R\left(Q_{i}\right)}{3}=0.06100
$$

And then divide all objects into groups according to the following pattern:

Group 1 for: $Q_{i} \in\left(\max Q_{i}-k, \max Q_{i}\right]$ in our case $(0,14351,0,20451]$

Group 2 for: $Q_{i} \in\left(\max Q_{i}-2 k, \max Q_{i}-k\right]$ in our case $(0,08251,0,14351]$

Group 3 for: $Q_{i} \in\left(\max Q_{i}-3 k, \max Q_{i}-2 k\right]$ in our case $(0,02151,0,08251]$

Table 7. Ranking of the EU countries according to armax rate presenting the value of changes in food consumer preferences in two extreme periods 2001-2003 and 2011-2013.

\begin{tabular}{|c|c|c|c|c|c|c|c|}
\hline Ranking & Country & $\operatorname{ar}_{\max }=Q_{i}$ & Groups & Ranking - cont. & Country - cont. & $\operatorname{ar}_{\max }=Q_{i}$ & Groups \\
\hline 1 & HR & 0.20451 & 1 & 15 & FR & 0.05783 & \multirow{14}{*}{3} \\
\hline 2 & $\mathrm{LT}$ & 0.12020 & \multirow{6}{*}{2} & 16 & GR & 0.05714 & \\
\hline 3 & BG & 0.11824 & & 17 & NL & 0.05589 & \\
\hline 4 & IE & 0.10422 & & 18 & $\mathrm{SE}$ & 0.05541 & \\
\hline 5 & ES & 0.09261 & & 19 & SI & 0.05435 & \\
\hline 6 & DK & 0.08719 & & 20 & GB & 0.05221 & \\
\hline 7 & SK & 0.08434 & & 21 & RO & 0.04766 & \\
\hline 8 & $\mathrm{EE}$ & 0.07820 & \multirow{7}{*}{3} & 22 & PL & 0.04302 & \\
\hline 9 & LU & 0.07510 & & 23 & FI & 0.03845 & \\
\hline 10 & LV & 0.07508 & & 24 & PT & 0.02971 & \\
\hline 11 & $\mathrm{HU}$ & 0.07366 & & 25 & IT & 0.02800 & \\
\hline 12 & AT & 0.06258 & & 26 & $\mathrm{CZ}$ & 0.02468 & \\
\hline 13 & MT & 0.06059 & & 27 & $\mathrm{DE}$ & 0.02152 & \\
\hline 14 & $\mathrm{BE}$ & 0.05901 & & & $\mathrm{k}$ & 0.06100 & \\
\hline
\end{tabular}

Source: Authors' own elaboration.

In the first group with the highest level of the investigated complex phenomenon, the biggest change in terms of nutritional preferences was found in Croatia. The second group with moderate nutritional preferences includes: Lithuania, Bulgaria, Ireland, Spain, Denmark and Slovakia and the third group, with the least significant changes, comprises of the rest of the EU countries (including Poland).

\section{Summary}

The method used in this paper to compare the consumption structures of different food product groups is one of many options for multidimensional analysis, but it is quite clear and produces quite good results as it is more sensitive to minor differences between the structures. The attempt to group European countries for food consumption in 1993 and 2000 was carried out with cluster analysis by Dudek and Orłowski (Dudek, Orłowski, 2006). However, despite changes in the consumption of food products in individual countries, the sets of countries in obtained concentrations in 2000 and 1993 were almost identical. 
The results of this study indicate that the structure of food consumption changed very slowly over a period of 10 years. The most visible difference, compared to other countries, may be observed in Croatia, which creates a separate, one-element group, indicating that its nutritional preferences have changed most strongly compared to other surveyed countries. This can be explained by the fact that in 2013 Croatia became a member of the European Union, and in the process of trying to obtain this privilege, it has undergone many economic changes, gained more access to other food products and export food prices decreased. As a result, its structure of consumption has become similar to other states of the EU. Analysis of this country example showed that the greatest change was observed in the consumption of potatoes and its products (x9). From a 15\% share in a group of investigational products, its consumption decreased to $6 \%$ (comparison on Fig.5). The consumption of dairy products increased significantly (from $25 \%$ to $32 \%$ ) and we observed a slight increase in meat consumption. This would confirm the research conducted over the past 40 years in the Mediterranean countries, which shows that in this region the consumption of milk and its products has constantly increased to the detriment of other products, such as cereals. (Balanza et al., 2007; Notarnicola et al., 2017).
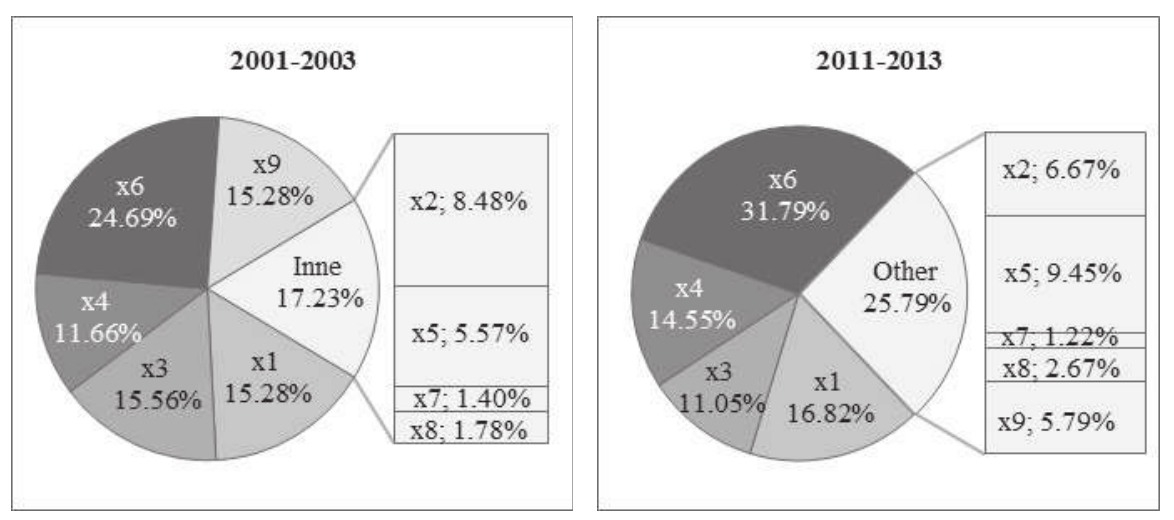

Fig. 5. The consumption of particular groups of products in Croatia (2001-2003) and (2011-2013)

Source: Authors' own elaboration.

A group of countries with average changes includes 6 countries: Lithuania, Bulgaria, Ireland, Spain, Denmark and Slovakia. The changes in the largest group (20 countries, including Poland) over ten years were very slight, and the structure of the food products has not actually changed, but the population has had similar nutritional preferences for years. The authors think that it would be interesting to do research in the future on the similar field but designed for food producers as useful information for defining possible food markets.

\section{References}

Arnold, B.C. (1987). Majorization and the Lorenz Order: A Brief Introduction, Lecture Notes in Statistics, v. 43, Springer-Verlag, Berlin.

Balanza, R., García-Lorda, P., Pérez-Rodrigo, C., Aranceta, J., Bonet, M. B., Salas-Salvadó, J. (2007). Trends in food availability determined by the Food and Agriculture Organization's food balance sheets in Mediterranean Europe in comparison with other European areas. Public health nutrition, 10(2),168-176. 
Binderman, Z., Borkowski, B., Szczesny, W. (2013). Zastosowanie metryki Minkowskiego do pomiaru zmian koncentracji. Metody Ilościowe w Badaniach Ekonomicznych, 14(3), 27-38.

Binderman, Z., Koszela, G., Szczesny, W. (2014). Zmiany w strukturze gospodarstw rolnych w krajach Unii Europejskiej w latach 2003-2010 (aspekty metodyczne). Zeszyty Naukowe Szkoły Głównej Gospodarstwa Wiejskiego w Warszawie. Problemy Rolnictwa Światowego, 14(3), 15-26.

Borkowski, B., Szczesny, W. (2005). Metody wizualizacji danych wielowymiarowych jako narzędzie syntezy informacji, Roczniki Naukowe SERIA, 7(5), 11-15.

De Amorim, R.C., Mirkin, B. (2012). Minkowski metric, feature weighting and anomalous cluster initializing in K-Means clustering. Pattern Recognition, 45(3), 1061-1075.

Dudek, H., Orłowski, A. (2006). Clustering of European Countries with Respect to Food Consumption. Acta Universitatis Lodziensis. Folia Oeconomica, 196, 217-228.

Food and Agriculture Organization of the United States. Accessed 06 November 2017 from: http://www.fao.org/economic/ess/en

Gastwirth, J.L. (1971). A general definition of the Lorenz curve, Econometrica, 39, 1037-1039.

Gini, C. (1914). Sulla misura della concentrazione e della variabilità dei caratteri, Atti del R. Istituto Veneto di Scienze Lettere ed Arti.

Glasser, G.J. (1962). Variance formulas for the mean difference and coefficient of concentration, Journal of the American Statistical Association, 57, 648-654.

Grzelak, A., Gałązka, M. (2013). Tendencje konsumpcji żywności w Polsce na tle uwarunkowań globalnych. Roczniki Ekonomiczne Kujawsko-Pomorskiej Szkoły Wyższej w Bydgoszczy, 6, 223-241.

Jain, A.K., Dubes, R.C. (1988). Algorithms for Clustering. Prentice-Hall, Inc. Upper Saddle River, NJ, USA

Koszela, G. (2016). Wykorzystanie gradacyjnej analizy danych do klasyfikacji podregionów pod względem struktury agrarnej. Wiadomości Statystyczne, 6, 10-30.

Kukuła, K. (red.) (2010). Statystyczne studium struktury agrarnej w Polsce, PWN, Warszawa

Kukuła, K. (2012). Propozycja budowy rankingu obiektów z wykorzystaniem cech ilościowych oraz jakościowych. Metody Ilościowe w Badaniach Ekonomicznych, 13(1), 5-16.

Kukuła, K. (2014a). Budowa rankingu województw ze względu na wyposażenie techniczne rolnictwa w Polsce, Wiadomości Statystyczne, 7, 62-76.

Kukuła, K. (2014b). Wybrane problemy ochrony środowiska w Polsce w świetle wielowymiarowej analizy porównawczej. Metody Ilościowe w Badaniach Ekonomicznych, 13(3), 276-287.

Małysa-Kaleta, A. (2003). Konsumpcja i zachowania konsumentów w Polsce w warunkach integracji europejskiej: wybrane zagadnienia. Prace Naukowe / Akademia Ekonomiczna w Katowicach.

Notarnicola, B., Tassielli, G., Renzulli, P.A., Castellani, V., Sala, S. (2017). Environmental impacts of food consumption in Europe. Journal of Cleaner Production, 140, 753-765.

Ząbkowski, T., Szczesny, W. (2012). Badanie atrakcyjności oferty dostępu do Internetu za pomocą analizy gradacyjnej. Metody Ilościowe w Badaniach Ekonomicznych, 15(3), 169-188.

Zimmermann, W. (1968). The power counting theorem for Minkowski metric. Communications in Mathematical Physics, 11(1), 1-8. 